\title{
原著論文
}

\author{
ペットボトルの形状に対する印象評価 \\ 矢澤 宗厚*, 成田 吉弘** \\ $*$ 北海道大学大学院, ${ }^{* *}$ 北海道大学工学研究院

\section{Evaluation of Impression to Pet - Bottle Shapes} \\ Muneatsu YAZAWA* and Yoshihiro NARITA** \\ * Graduate School of Engineering, Hokkaido University, 13-8 kitaku, Sapporo, 060-8628, Japan \\ ** Faculty of Engineering, Hokkaido University
}

\begin{abstract}
Recent commercial products tend to have various appearances with curved surfaces. This is because attractive outer designs stimulate consumers' motivation for purchasing. This paper attempts to study how the bottle shapes affect our impression. The approach consists of three parts. First, three-dimensional models are fabricated to imitate shapes of widely circulated PET bottles, and thirty five examinees rate their impression by answering questionnaires. Measured objects have nine different bottle shapes with specific features. Twelve adjective pairs are chosen for the use in questionnaires to describe model features. Then, the results from the questionnaires are studied by the analysis of variance to clarify the significant differences among impressions caused by variously curved shapes. Finally, the results are analyzed by using the factor analysis to get the factor scores.
\end{abstract}

Keywords : PET bottles, Shape design, Impression

\section{1.はじめに}

現在，身のまわりに流通する商品群には，様々な形状デザ インが用いられている. 最近の商品は, 機能や品質が高水準 であるのは当然とされ，それに新たなプラスアルファが求め られている。とくに良いセンスを持ち，感性にアピールする 外観デザインは強い印象を与え, 購買意欲を刺激する主要因 子と言える [1].

このように形状は，視覚と触覚に大きく影響を与えるた め, 現在までに製品の形状に関する研究が行われている。例 えば, 製品の色と形状の最適な組合せを視覚的に求める研究 ［2］や，製品の厚さを感じ取る触覚に関する研究［3］など がある，特に曲線については，原田ら $[4,5]$ により自動車 外形形状デザイン支援システムや曲線の性質についての一連 の研究がある。著者らも, 柱状体の曲面における印象と, そ の男女のジェンダー差に関して報告している [6].

現在広く流通する商品の中で, 高さや幅が規格化され, 様々 な形状デザインが存在するものとしてPET (Polyethylene Terephthalate）材料から作られるペットボトル飲料容器が 挙げられる。ペットボトルは1970年代後半にしょうゆ容器 として初めて使用され，1980年代に大型の飲料容器, 1990 年代に入り $500 \mathrm{ml}$ 以下のペットボトル飲料が普及した。こ のペットボトルは，似た形状であっても部分的にデザインの 変化を持たせることが可能で，そのデザインの違いにより販 売力に違いを生じる可能性がある。したがってデザインの差 異に関して, 消費者が受ける印象評価の研究が重要となる.

本研究では, 基本的な特徵を持たせたペットボトルのモデ ルを作成して, 部分的なデザインの違いによる印象の差を調
ベる、そのため9種類のモデルに対して，被験者に 12 対の 形容詞対からなるアンケートの回答を依頼して評価を行う. そのデータをもとに，モデルの分類ごとに分散分析，因子分 析を用いて解析を行い，印象の差異を考察する。被験者は 22歳〜26歳の男性33名, 女性2名である.

\section{2. 評 価 方 法}

\section{1 評 価 対 象}

図 1 は, 本研究で用いたペットボトルを模擬した 9 種類の 実物大三次元（3D）モデルである。モデルの高さは共通と して，219 mmとした。 モデルは大別して三つのグループ

(a) No.1 No.3：丸型の断面を持つグループ（丸型断面モ デル)

（b）No.4〜No.6：角型の断面を持つグループ（角型断面モ デル)

(c) No.7 No.9：六角型断面を持つグループ (六角型断面 モデル）

となっている，各グループ内での違いは，

No.1 No.3：軸方向の曲面形（凹曲面, 円筒面, 凸曲面）

No.4 No.6：溝の上下位置

No.7 No.9：肩の位置と形 となっている。また三つのグループ間で比較する場合には,

(d) No.2, No.5, No.8

を（a）（b）（c）からのグループの代表（代表型断面モデル） とした.

これらのペットボトルのモデル形状は，3次元CADソフ

ト Solid Worksにより数值モデル化して, Roland社の MODELA MDX - 40を用いて実物大3Dモデルの加工をし 


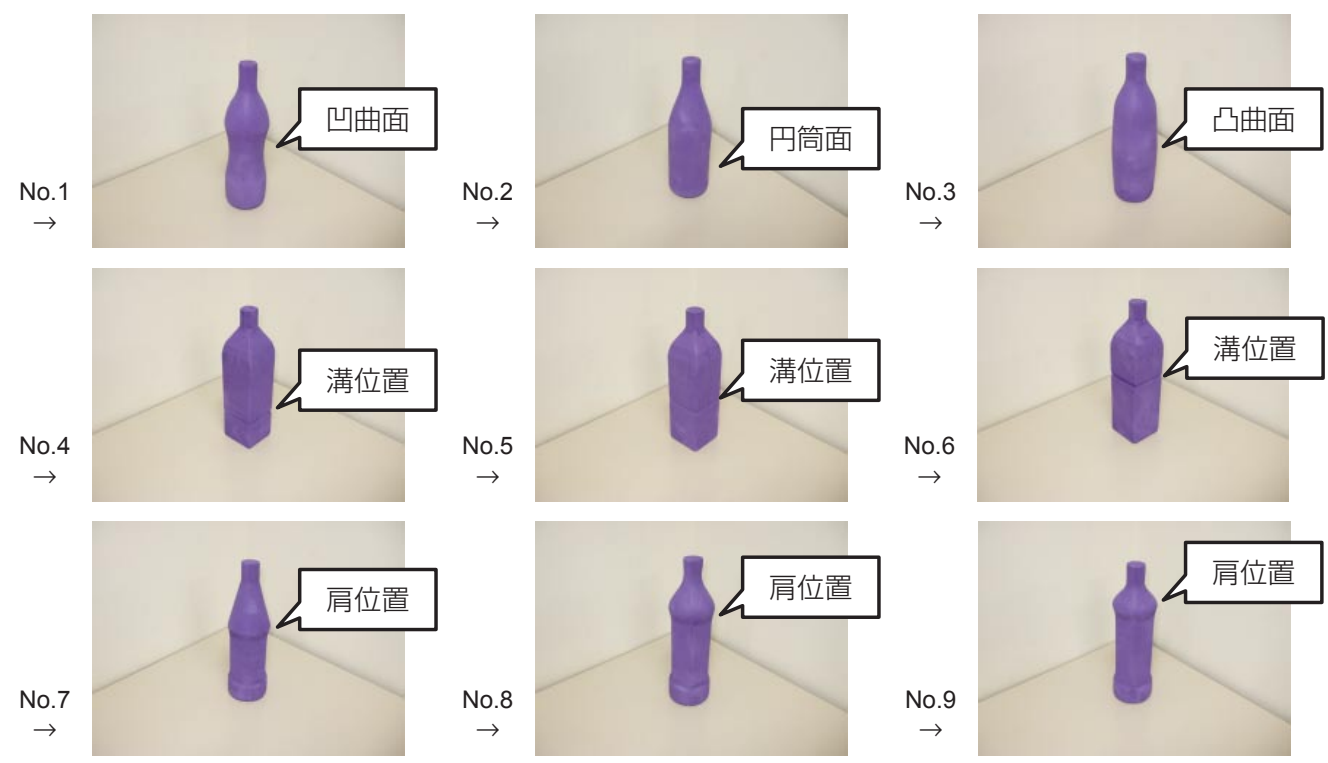

図1 測定対象となった実物大3Dモデル

た．モデル材料は発泡材料である．印象評価には色の影響が 大きいが，本研究では色の影響を排除するためモデルを淡い 紫色に着色した。 これは, 小林の研究 [7］の考え方を採用 して, すべての色が「ウォーム (W : warm) -クール (C :

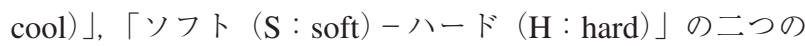
心理軸に整理されることを前提に, その二軸座標の原点付近 に位置する紫を用いている。

\section{2 被験者・評価項目・評価手順}

本研究の被験者は22歳〜26歳までの男性 33 名, 女性 2 名 の合計 35 名である。評価項目は，12組の形容詞対を選択して

(1)「大きいー小さい」(Big - Small),

(2)「美しいー醜い」(Beautiful - Ugly),

(3)「重々しいー軽々しい」(Heavy - Light),

(4)「変形しにくい-変形しやすい」(Undeformable Deformable),

(5)「丸みのある一角ばった」(Roundish - Square),

(6)「単純なー複雑な」(Simple - Complex),

(7)「鮮明なーぼんやりした」(Sharp - Obscure),

(8)「硬い一軟らかい」(Hard - Soft),

(9)「強いー弱い」(Strong - Weak),

(10)「明るいー暗い」(Bright - Dark),

(11)「温かいー冷たい」(Warm - Cold),

(12)「たくましいー弱々しい」(Tough - Tender)

とした。これらの評価用語は, 文献 $[8]$ を参考に, 形の印 象を形容する形容詞対を選んだ。また上記のうち，(4)変形し にくいー変形しやすい, 8硬い一軟らかい, (9)強い一弱い, は強度や力学に関する形容詞対であり, ボトルに必要な工学 的な観点を取り込んでいる。

評価の方法は，12項目に対して 5 段階尺度で評価させた。 評価手順は, 9種類の評価対象を, くじによりランダム順に 提示し, 1 サンプルについて1分間で12項目の評価を行った。

\section{3. データ解析の結果と考察}

\section{1 アンケート分散分析結果と考察}

9 種類のモデルに対して，グループ（a）（b）（c）内の形 状の変化による印象の評価と, 各グループの代表による代表 型（d）の特性を調べた。アンケートの中央值は 0 とし, 左 の形容詞の印象が強ければプラス（最大值2), 右側の形容 詞の印象が強ければマイナス（最小值-2）の值とした

その結果に対し，先に述べた（a）（b）（c）（d）の分類ご とに，形状要因による分散分析（被験者内計画）を行った. 球面性検定には，Mendozaの球面性検定 [9] を用い，球面 性の仮定が成り立たない場合, Greenhouse - Geisserの $\varepsilon （$ 自 由度調整值）［10］により自由度を調整した。表 1 4のpは 有意確率を表す。多重比較にはShafferの方法 $(a=0.05)(a$ : 有意水準）を用いた［11-13].

\section{（a）丸型断面モデル（No.1～3）}

図 2 は, 丸型断面モデルに対するアンケート結果の平均值 をグラフ化したものである。 その分散分析の結果を表 1 に載 せる. No.1, No.2, No.3の間の比較は以下にまとめられる. 形容詞対 (1)「大きいー小さい」に関しては, No.1, No.2, No.3の順に小さく感じる.

(2)「美しいー醜い」に関しては, No.1とNo.2の間に有意 差は見出せないが, どちらもNo.3より美しく感じる.

(3)「重々しいー軽々しい」は, No.1 と No.2の間に有意差 は見出せないが, どちらもNo.3よりも軽いと感じる.

(4)「変形しにくいー変形しやすい」に関して形状による主 効果は有意であったが $(\mathrm{F}(1.57,53.31)=3.474, \mathrm{p}<0.05)$, No.1〜No.3に有意な差は見られなかった。

(5)「丸みのあるー角ばった」に関して形状による主効果は 認められなかった。

(6)「単純な - 複雑な」は, No.1が最も複雑に感じ, 


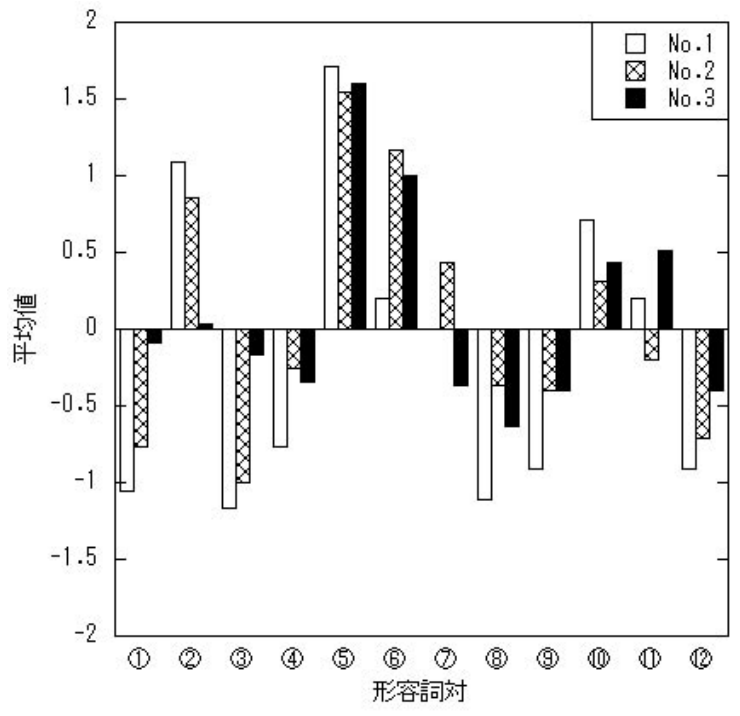

図2 丸型断面モデルに対する形容詞対評価の平均値

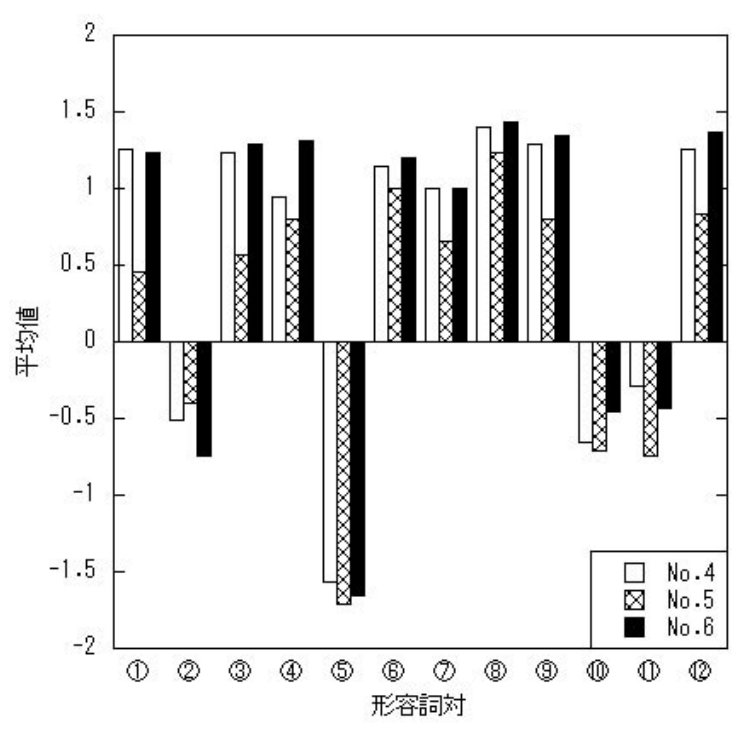

図3角型断面モデルに対する形容詞対評価の平均値

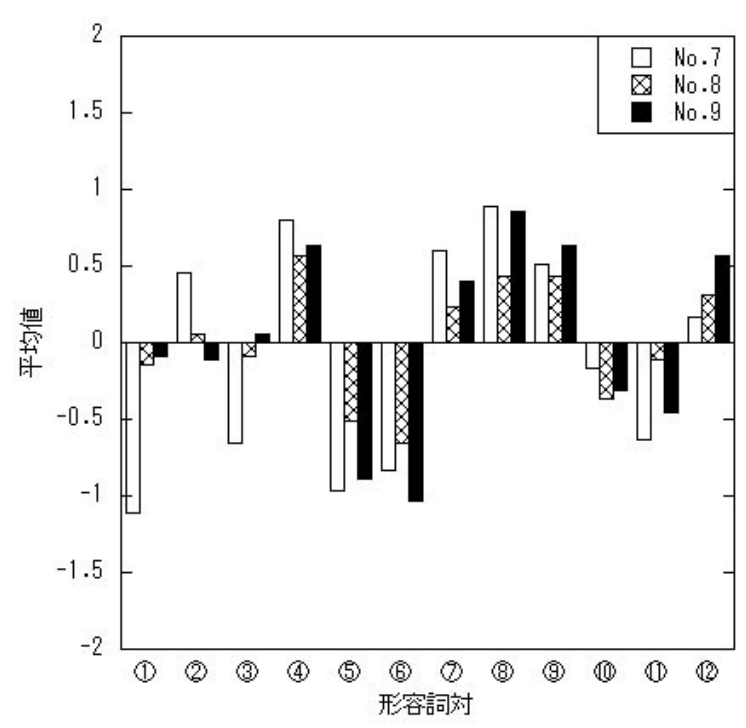

図4 六角型断面モデルに対する形容詞対評価の平均値
No.2, No.3の間に有意差は見出せずNo.1より単純である.

(7)「鮮明なーぼんやりした」に関しては, No.1とNo.3の 間に有意な差は見出せないが, どちらもNo.2よりもぼやけ て感じる。

(8)「硬い一軟らかい」は, No.1が最も軟らかく感じ,

No.2, No.3の間に有意な差は見出せないが, どちらも No.1 よりも硬く感じる.

(9)「強いー弱い」は, No.1が最も弱く, No.2, No.3の間 に有意な差は見出せないが, どちらもNo.1より強く感じる.

(10)「明るいー暗い」に関しては，No.2よりもNo.1が明る く感じ, No.3はNo.1, No.2 との間に有意な差は見出せない.

(11「温かいー冷たい」に関しては, No.1とNo.3の間に有意 な差は見出せないが, どちらもNo.2よりも温かいと感じる.

(12)「たくましいー弱々しい」に関しては, No.1よりも No.3がたくましいと感じるが, No.1, No.3ともにNo 2 と は有意な差は見出せなかった。

以上のように，(5)「丸みのある一角ばった」以外は主効果 が認められたが, 断面が丸型は形状がすべて丸みのあるもの なので，(5)はこのような結果となったと考えられる。また,

(4)「変形しにくいー変形しやすい」に関して主効果は認めら れたが，モデル間での有意差は認められず，丸型内では変形 しやすさという点で, 差異を感じられない結果を示した。

\section{（b）角型断面モデル（No.4〜6）}

図3は角型断面モデルのアンケート結果の平均值をグラフ 化したものである。また分散分析の結果を表 2 に載せる.

No.4, No. 5, No.6の間で比較を行うと, 以下の結果が観察 された.

形容詞対(1)「大きいー小さい」に関しては, No.4とNo.6 の間に有意な差は見出せないが，どちらもNo.5より大きく 感じる.

(3)「重々しいー軽々しい」に関しては, No.4とNo.6の間 に有意な差は見出せないが, どちらもNo.5より重く感じる.

(4)「変形しにくいー変形しやすい」に関しては, No.4 と No.5の間に有意な差は見出せないが, この二つよりNo.6の 方が変形しにくいと感じる.

(7)「鮮明なーぼんやりした」に関して形状による主効果は やや有意であったが $(\mathrm{F}(2,68)=2.4591, \mathrm{p}<0.1)$, No.4

〜No.6の間に有意な差は見られなかった.

(9)「強いー弱い」に関しては, No.4とNo.6の間に有意な 差は見出せないが, どちらもNo.5より強く感じる。

(11)「温かいー冷たい」に関しては, No.5よりもNo.4が温 かいと感じるが, No.4, No.5ともにNo.6とは有意な差は見 出せなかった。

(12)「たくましいー弱々しい」に関しては, No.4とNo.6の 間に有意な差は見出せないが，どちらもNo.5よりたくまし く感じる.

以上をまとめると，(2)，(5)，(6)，8，(10に関して形状によ る主効果は認められなかった。 分散分析の結果から, (4)の形 容詞対以外にはNo.4とNo.6の間に差がなく, 溝の位置が上 
と下の場合は印象が同じという結果となった.

\section{（c）六角型断面モデル（No.7～9）}

図4は, 六角型断面モデルのアンケート結果の平均值をグ ラフ化したものである。分散分析の結果を表 3 に載せる.

形容詞対 (1)「大きいー小さい」に関しては, No.8 と No.9 の間に有意な差は見出せないが, どちらもNo.7より大きい と感じる

(2)「美しいー醜い」に関しては, No.8 と No.9の間に有意 な差は見出せず, No.7はNo.8, No.9より美しいと感じる.

(3)「重々しいー軽々しい」に関しては, No.8 と No.9の間 に有意な差は見出せないが, どちらもNo.7より重く感じる。

(5)「丸みのある一角ばった」に関して形状による主効果は 有意であったが $(\mathrm{F}(2,68)=3.585, \mathrm{p}<0.05)$, No.7〜 No.9の間に有意な差は見られなかった。

(6)「単純なー複雑な」に関して形状による主効果はやや有 意であったが $(\mathrm{F}(1.56,53.2)=2.982, \mathrm{p}<0.1)$, No.7〜 No.9の間に有意な差は見られなかった。

(8)「硬い一軟らかい」に関しては, No.7とNo.9の間に有 意な差は見出せないが, どちらもNo.8 より硬いと感じると いう結果となった

(11)「温かいー冷たい」に関しては, No.7よりもNo.8が温 かいと感じるが, No.7, No.8 ともにNo.9とは有意な差は見 出せなかった。このように，(4)，(7)，(9)，(10)，(12)に関して形 状による主効果は認められなかった。

図4からは, 形容詞対(2), (3)以外はモデル間で傾向が一致 していることがわかる. 形容詞対 (4), (9), (12)といった強さに 関連する形容詞対については, 形状による主効果が現れなかっ た.この点に関して, 肩の位置の違いでは差が生じない結果 となった.No.8 とNo.9の間に有意な差があったのは80のみ であり，他の形容詞対に関しては差が見られなかった。これ はNo.8, No.9の肩の位置の差が, No.7と No.8, No.7と No.9 程の差ではないため,このような結果となったと考えられる.

\section{（d）代表型断面モデル（No.2，5，8）}

図 5 は，（a）（b）（c）の各グループからの代表型断面モデ ルのアンケート結果の平均值をグラフ化したものである。そ の分散分析の結果を表4に載せる. No.2, No.5, No.8で比 較を行うと, 以下の結果となった。

形容詞対 (1)「大きい一小さい」に関しては, No.2, No.8, No.5の順に小さく感じる.

(2)「美しいー醜い」に関しては, No.2, No.8, No.5の順 に美しいと感じる

(3)「重々しい-軽々しい」に関しては, No.2, No.8, No.5の順に軽く感じるという結果となった.

(4)「変形しにくいー変形しやすい」に関しては, No.5 と No.8の間に有意な差は見出せないが, どちらもNo.2より変 形しにくいと感じる。

(5)「丸みのある一角ばった」に関しては, No.2, No.8, No.5の順に丸く感じる.
表1 丸型断面モデルの分散分析結果

\begin{tabular}{|c|c|c|}
\hline 形容詞対 & 主効果 & 多重比較 \\
\hline (1)大きいー小さい) & $* * *$ & No. $1<$ No. $2<$ No.3 \\
\hline (2)美しいー醜い) & $* * *$ & No.3 $<$ No.1 = No.2 \\
\hline (3)重々しいー軽々しい & $* * *$ & No.1 $=$ No. $2<$ No.3 \\
\hline (4)変形しにくいー変形しやすい & * & No.1 $=$ No. $2=$ No.3 \\
\hline (5)丸みのある一角ばつた & n.s. & - \\
\hline (6)単純なー複雑な & $* * *$ & No. $1<$ No. $2=$ No.3 \\
\hline (7)鮮明なーぼんやりした & $* *$ & No.1 $=$ No.3 $<$ No.2 \\
\hline 8硬いー軟らかい & $* * *$ & No. $1<$ No. $2=$ No.3 \\
\hline (9)強いー弱い & $* *$ & No. $1<$ No. $2=$ No.3 \\
\hline (10)明るいー－暗い & * & $\begin{array}{c}\text { No.1 }>\text { No.2 } \\
\text { No.2 }=\text { No.3, No.1 = No.3 }\end{array}$ \\
\hline (11温かいー冷たい & $* * *$ & No.1 $=$ No.3 $>$ No.2 \\
\hline (12たくましいー弱々しい & * & $\begin{array}{c}\text { No. } 1<\text { No.3 } \\
\text { No.1 }=\text { No. } 2, \text { No. } 2=\text { No.3 }\end{array}$ \\
\hline
\end{tabular}

(n.s.: not significant, $+: \mathrm{p}<0.1$

$*: p<0.05, * *: p<0.01, * *: p<0.001)$

\section{表2 角型断面モデルの分散分析結果}

\begin{tabular}{|c|c|c|}
\hline 形容詞対 & 主効果 & 多重比較 \\
\hline (1)大きいー小さい & *** & No.4 $=$ No. $6>$ No. 5 \\
\hline (2)美しいー醜い) & n.s. & - \\
\hline (3)重々しいー軽々しい & $* * *$ & No.4 $=$ No. $6>$ No. 5 \\
\hline (4)変形しにくいー変形しやすい & * & No.4 $=$ No. $5<$ No. 6 \\
\hline (5)丸みのあるー角ばった & n.s. & - \\
\hline (6)単純なー複雑な & n.s. & - \\
\hline (7)鮮明なーぼんやりした & + & No.4 $=$ No. $5=$ No. 6 \\
\hline 8硬いー軟らかい & n.s. & - \\
\hline (9)強いー弱い & $* *$ & No.4 $=$ No. $6>$ No. 5 \\
\hline (10)明るいー暗い & n.s. & - \\
\hline (11温かいー冷たい & + & No.4 > No.5 \\
\hline & & No.4 $=$ No.6, No. $5=$ No. 6 \\
\hline (12)たくましいー弱々しい & $* *$ & No. $4=$ No. $6>$ No. 5 \\
\hline
\end{tabular}

\section{表3 六角型断面モデルの分散分析結果}

\begin{tabular}{|c|c|c|}
\hline 形容詞対 & 主効果 & 多重比較 \\
\hline (1)大きいー小さい & $* * *$ & No.7 $<$ No.8 $=$ No.9 \\
\hline (2)美しいー－醜い) & $* *$ & No.7 $>$ No.8 $=$ No.9 \\
\hline (3)重々しいー軽々しい & ** & No.7 $<$ No.8 $=$ No.9 \\
\hline (4)変形しにくいー変形しやすい & n.s. & - \\
\hline (5丸みのあるー角ばった & * & No.7 $=$ No.8 $=$ No.9 \\
\hline (6)単純なー複雑な & + & No.7 $=$ No.8 $=$ No.9 \\
\hline (7)鮮明なーぼんやりした & n.s. & - \\
\hline 8硬いー軟らかい & $* *$ & No.7 $=$ No.9 $>$ No.8 \\
\hline (9)強いー弱い & n.s. & - \\
\hline (10)明るいー暗い & n.s. & - \\
\hline (11温かいー冷たい & $*$ & No.7 $<$ No.8 \\
\hline & & No.8 $=$ No.9, No.7 $=$ No.9 \\
\hline (12)たくましいー弱々しい & n.s. & - \\
\hline
\end{tabular}

(n.s.: not significant, + : $p<0.1$, $*: p<0.05, * *: p<0.01, * * *: p<0.001)$ 
(6「単純なー複雑な」に関しては, No.8が最も複雑に感じ,

No.2, No.5の間に有意な差は見出せなかった.

(7)「鮮明なーぼんやりした」に関して形状による主効果は 認められなかった。

(8)「硬いー軟らかい」に関しては, No.5, No.8, No.2の 順に硬く感じる.

(9)「強いー弱い」に関しては, No.2が最も弱く感じ,

No.5, No.8の間に有意な差は見出せないが, No.2よりは強 く感じる.

(10)「明るいー暗い」に関しては, No.2が最も明るく感じ,

No.5, No.8の間に有意な差は見出せず, 暗いと感じる.

(11)「温かいー冷たい」に関しては, No.2 と No.8の間に有 意な差は見られず, No.5が最も冷たく感じる.

(12)「たくましいー弱々しい」に関しては，No.5, No.8, No.2の順にたくましく感じる.

以上をまとめると, 形容詞対(7)以外は形状による主効果が 有意であった，どの形状も「鮮明さ」という点では変わらな

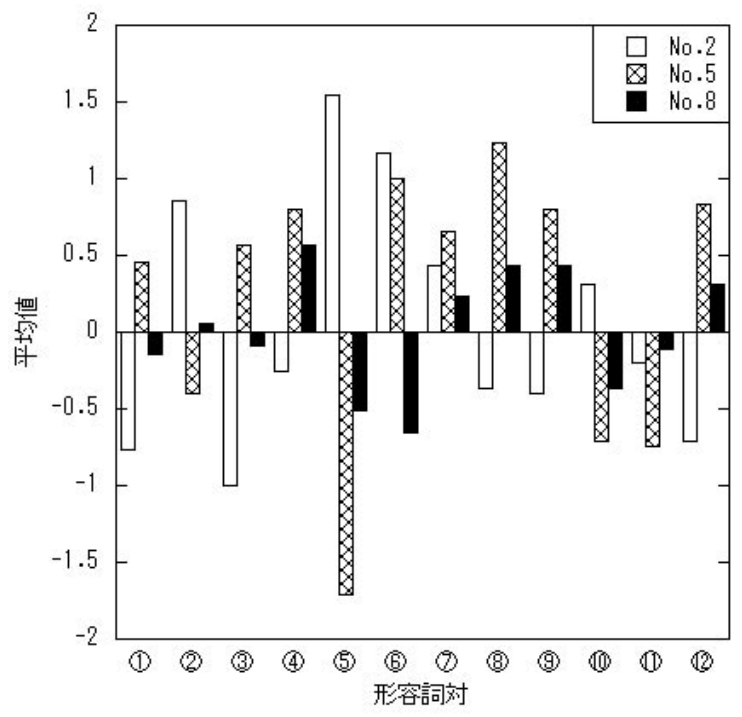

図5 代表型断面モデルに対する形容詞対評価の平均値

\section{表4 代表型断面モデルの分散分析結果}

\begin{tabular}{|c|c|c|}
\hline 形容詞対 & 主効果 & 多重比較 \\
\hline (1)大きいー小さい & $* * *$ & No. $2<$ No.8 $<$ No. 5 \\
\hline (2)美しい－醜い) & *** & No. $5<$ No.8 $<$ No. 2 \\
\hline (3)重々しいー軽々しい & $* * *$ & No. $2<$ No.8 $<$ No. 5 \\
\hline (4)変形しにくいー変形しやすい & $* * *$ & No. $2<$ No. $5=$ No. 8 \\
\hline (5)丸みのある一角ばった & $* * *$ & No. $5<$ No.8 $<$ No. 2 \\
\hline (6)単純なー複雑な & $* * *$ & No. $8<$ No. $2=$ No. 5 \\
\hline (7)鮮明なーぼんやりした & n.s. & - \\
\hline 8硬いー軟らかい & $* * *$ & No. $2<$ No. $8<$ No. 5 \\
\hline (9)強い－弱い & $* * *$ & No. $2<$ No. $5=$ No. 8 \\
\hline (10明るいー暗い) & *** & No. $2>$ No. $5=$ No.8 \\
\hline (11温かいー冷たい & * & No. $2=$ No. $8>$ No. 5 \\
\hline (12)たくましいー弱々しい & *** & No. $2<$ No. $8<$ No. 5 \\
\hline
\end{tabular}

(n.s.: not significant, + : $p<0.1$,

$*: p<0.05, * *: p<0.01, * * *: p<0.001)$
い. No. 2 とNo. 8 , No. 5 とNo.8の間に有意な差がない形容 詞対がいくつかあり，丸型と角型を合わせた形の六角型では あるが，すべての形容詞対に関して中間の值となるわけでは なく，丸型に近い場合と角型に近い場合が見受けられた。

\section{2 アンケート因子分析結果・考察}

アンケート結果に対し，先に述べた四つのグループ (a) （b）（c）（d）ごとに因子分析を行った。 因子分析手法には 最尤法, 因子軸回転方法には直接オブリミン法を用いた。最 尤法の採用には, 最小二乗法との結果を比較して差異がない ことを確認し，その妥当性を検証した [10]. 回転法につい ては, 直交回転では相関があった場合にも現れないが, 斜交 回転であれば因子間の相関が顕在化して，なければ直交とな るため長所を生かして, 斜交回転の直接オブリミン法を採用 した. 因子数決定方法には対角 SMC (Squared Multiple Correlation）の 95\%点平行分析と MAP（Minimum Average Partial）の挟みうちを行い，解釈の容易性により決定し た。また，モデル適合度はRMSEA（Root Mean Square Error of Approximation) と AIC (Akaike's Information Criterion）を参照にした。

その後, 因子分析により得られた因子得点に対し, 形状要 因による分散分析（被験者内計画）を行った。アンケート結 果に対する分散分析と同様に, 球面性検定にはMendozaの 球面性 [8］検定を用い, 球面性の仮定が成り立たない場合, Greenhouse - Geisserのとにより自由度を修正している [10]. 多重比較にはShafferの方法 $(a=0.05)$ を用いた $[11$, 12]. 以降で各断面モデルにおいて平均值のグラフを提示し ており, サンプル数はそれぞれ 105 となっている. また検定 は全サンプルで実施した。

\section{（a）丸型断面モデル（No.1〜3）}

表 5 は丸型の因子分析結果である, 上述の方法により, 因 子数は 3 と決定した。適合度はRMSEA $=0.042, \mathrm{AIC}=$ -11.92 であり, 妥当とした。 得られた第 1 因子は強い, 硬い, たくましいから構成されており,「強さの因子」と命名した。 第 2 因子は明るい, 温かいから構成されており, 温かいもの は明るいというイメージよりも明るいものは温かいというイ メージの方が一般的であると考え,「明るさの因子」と命名 した。第3因子は軽々しい, 美しい, 小さい, 鮮明なから構 成されており, 古典的な男女差のイメージより「ジェンダー の因子」と命名した.

図6に因子得点の平均值をグラフ化したものを載せる. 分 散分析を行った結果, 因子 $1 ， 2 ， 3$ すべて形状による主効果 が有意であった（因子 $1: \mathrm{F}(2,68)=7.865, \mathrm{p}<0.001$; 因子 $2: \mathrm{F}(1.66,56.38)=6.754, \mathrm{p}<0.005$; 因子 $3: \mathrm{F}(1.36$, 46.41) $=27.498, \mathrm{p}<0.001)$.

第 1 因子に関しては, No.2, No.3の間に有意な差は見ら れなかったが, どちらもNo.1より強いという印象を与える 結果となった，第2因子に関しては，No.1，No.3の間に有 意な差は見られなかったが, どちらもNo.2より明るいとい 
う印象を与える結果となった。第3因子に関しては，No.1， No.2の間に有意な差は見られなかったが，どちらもNo.3よ り女性的という印象を与える結果となった。

No.1であれば弱い，No.2であれば暗い，No.3であれば男性 的といったように，どの因子の因子得点においても，どれか 一つのモデルが他の二つとは別の印象を与える結果を得た。

\section{（b）角型断面モデル（No.4～6）}

表6は角型の因子分析結果である. 同様の方法により, 因 子数は 2 と決定した。適合度はRMSEA $=0.000, \mathrm{AIC}=$ -15.95であり，妥当とした。第1因子はたくましい，強い， 重々しい，変形しにくい，鮮明なから構成されており，「強 さの因子」と命名した，第2因子は明るい, 美しい, 温かい から構成されており,「明るさの因子」と命名した。

図7に，因子得点の平均值をグラフ化したものを載せる。 因子に関わらず，形状による傾向は一致していることがわか る. No.4とNo.6はy 軸上プラスの值であり, No.5のみマイ ナスの值となっている. 分散分析を行った結果, 因子 1 に関 して形状による主効果が有意であった $(\mathrm{F}(2,68)=7.8652$, $\mathrm{p}<0.001)$ ．第 1 因子に関して, No.4, No.6の間に有意な差 は見られなかったが, どちらもNo.5より強い印象を与える 結果となった。明るさの因子に関しては, 溝の位置の違いで は差が生じない結果となった。

\section{（c）六角型断面モデル（No.7〜9）}

表7は六角型の因子分析結果である. 同様の方法により因 子数を 3 と決定した。適合度はRMSEA $=0.000, \mathrm{AIC}=$ -15.04であり，妥当とした。第1因子は重々しい，大きい, たくましいから構成されており,「重厚さの因子」と命名した。 第 2 因子は強い, 鮮明な, 美しいから構成されており,「機能 美の因子」と命名した。第3因子は温かい, 明るいから構成 されているので, 丸型と同様に「明るさの因子」と命名した。

図 8 に, 因子得点の平均值をグラフ化する. グラフの変化 傾向より, No.7のみ別の印象を与えると考えられる. 分散 分析を行った結果, 因子 1,2 において形状による主効果が 有意であった（因子 $1 ： \mathrm{~F}(2,68)=12.312, \mathrm{p}<0.001$; 因 子 $2: \mathrm{F}(2,68)=2.956, \mathrm{p}<0.1)$. 第 1 因子に関しては, No.8, No.9の間に有意な差は見られなかったが, どちらも No.7より重厚であるという印象を与える結果となった。第2 因子に関しては，主効果は有意であったが，No.7，No.8， No.9の間に有意な差は見られなかった.

\section{（d）代表型断面モデル（No.2，5，8）}

表 8 は, 代表型の因子分析結果である. 上と同様の方法に より，因子数は 3 と決定した。適合度はRMSEA $=0.129$, $\mathrm{AIC}=-7.75$ であり，他の場合の因子分析結果に比べ，良い 結果とはいえないが, 複数のモデルと比較した結果, これが 最も良いモデルであったので採用した，第 1 因子は大きい, 重々しい, たくましい, 角ばった, 強いから構成されており, 「重厚さの因子」と命名した，第 2 因子は鮮明な, 硬いから
構成されており，丸みを帯び，ふわふわしたようなものはや わらかく，直線的で角ばっており，はっきりと眼に映るもの は硬いという一般的イメージから「感触の因子」と命名した。 第3 因子は明るい，美しい，温かいから構成されており，「明 るさの因子」と命名した。

図9に因子得点の平均值を載せる。眓より，第 2 因子の因 子得点は第 1 , 第 3 因子得点の間にあることがわかる。 また, 形状による傾向がはっきりと出ており，No.2の丸型とNo.5 の角型の中間の形状と言えるNo.8の六角型の因子得点は,

No.2 と No.5の間の值をとることがわかる.

分散分析を行った結果, 因子 $1 ， 3$ において形状による主

表5 丸型断面モデルの因子分析結果

\begin{tabular}{|c|c|c|c|c|}
\hline & 因子1 & 因子2 & 因子3 & 共通性 \\
\hline 強い－弱い & 0.813 & -0.017 & -0.015 & 0.662 \\
\hline 硬いー軟らかい & 0.727 & -0.369 & -0.033 & 0.666 \\
\hline たくましいー弱々しい & 0.683 & 0.162 & -0.134 & 0.511 \\
\hline 明るいー暗い & 0.019 & 0.726 & 0.225 & 0.578 \\
\hline 温かいー冷たい & -0.104 & 0.711 & -0.234 & 0.570 \\
\hline 重々しいー軽々しい & 0.433 & 0.072 & -0.688 & 0.666 \\
\hline 美しいー醜い & 0.098 & 0.315 & 0.682 & 0.574 \\
\hline 大きいー小さい & 0.267 & 0.211 & -0.659 & 0.549 \\
\hline 鮮明なーぼんやりした & 0.335 & -0.070 & 0.347 & 0.237 \\
\hline 寄与度 & 2.048 & 1.348 & 1.617 & 5.014 \\
\hline 因子寄与率（\%） & 22.757 & 14.978 & 17.971 & 55.707 \\
\hline
\end{tabular}

表6 角型断面モデルの因子分析結果

\begin{tabular}{|c|c|c|c|}
\hline & 因子1 & 因子2 & 共通性 \\
\hline たくましいー弱々しい & 0.848 & 0.047 & 0.722 \\
\hline 強いー弱い & 0.789 & -0.001 & 0.622 \\
\hline 重々しい一軽々しい & 0.747 & -0.128 & 0.574 \\
\hline 変形しにくいー変形しやすい & 0.743 & -0.093 & 0.560 \\
\hline 鮮明なーぼんやりした & 0.480 & 0.227 & 0.282 \\
\hline 明るいー暗い & -0.115 & 0.756 & 0.584 \\
\hline 美しい－醜い & -0.014 & 0.542 & 0.294 \\
\hline 温かいー冷たい & 0.091 & 0.531 & 0.290 \\
\hline 寄与度 & 2.703 & 1.224 & 3.927 \\
\hline 因子寄与率 (\%) & 33.784 & 15.306 & 49.089 \\
\hline
\end{tabular}

表7 六角型断面モデルの因子分析結果

\begin{tabular}{|c|c|c|c|c|}
\hline & 因子1 & 因子2 & 因子3 & 共通性 \\
\hline 重々しいー軽々しい & 0.768 & -0.098 & -0.049 & 0.603 \\
\hline 大きいー小さい & 0.691 & 0.048 & 0.125 & 0.496 \\
\hline たくましいー弱々しい & 0.512 & 0.486 & 0.030 & 0.500 \\
\hline 強い－弱い & 0.398 & 0.773 & -0.246 & 0.816 \\
\hline 鮮明なーぼんやりした & -0.088 & 0.710 & 0.050 & 0.514 \\
\hline 美しいー醜い & -0.150 & 0.365 & 0.320 & 0.258 \\
\hline 温かいー冷たい & 0.161 & -0.171 & 0.684 & 0.523 \\
\hline 明るいー暗い & -0.084 & 0.208 & 0.597 & 0.406 \\
\hline 寄与度 & 1.552 & 1.554 & 1.008 & 4.114 \\
\hline 因子寄与率（\%） & 19.403 & 19.427 & 12.600 & 51.430 \\
\hline
\end{tabular}


効果が有意であった（因子 $1: F(2,68 ）=63.652, \mathrm{p}<0.001$; 因子 $3: F(2,68)=31.489, p<0.001)$. 第 1 因子に関しては, No.5, No.8, No.2の順に重厚であるという印象を与えると いう結果となった。第3因子に関しては, No.2, No.8, No.5 の順に明るさの因子が高い印象を与える結果となった。

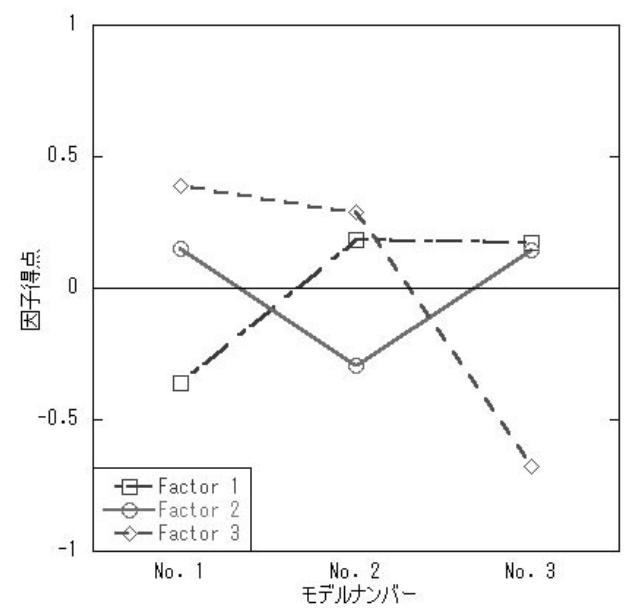

図6 丸型断面モデルの因子得点

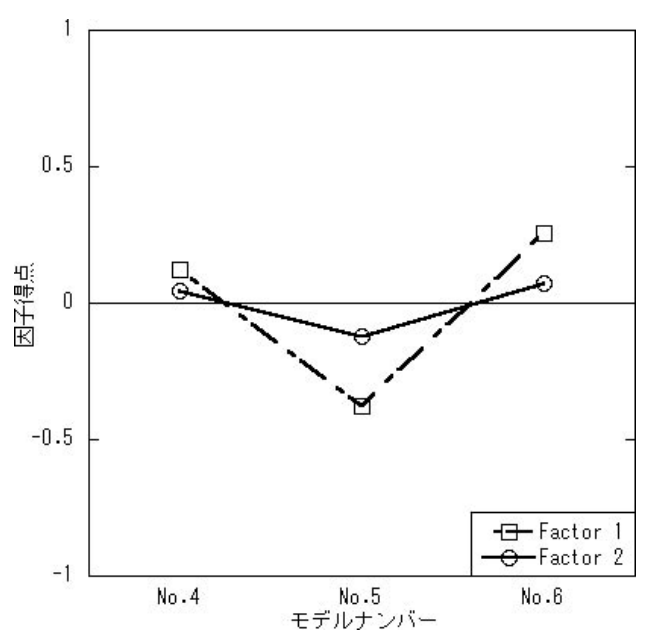

図7 角型断面モデルの因子得点

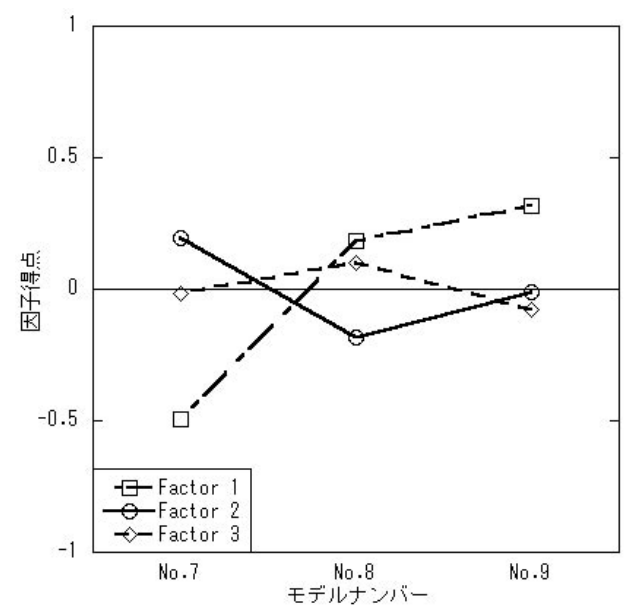

図8 六角型断面モデルの因子得点
表8 代表型断面モデルの因子分析結果

\begin{tabular}{|c|c|c|c|c|}
\hline & 因子 1 & 因子2 & 因子3 & 共通性 \\
\hline 大きいー小さい & 0.812 & -0.034 & 0.097 & 0.669 \\
\hline 重々しいー軽々しい & 0.782 & -0.113 & -0.041 & 0.626 \\
\hline たくましいー弱々しい & 0.780 & 0.247 & 0.132 & 0.687 \\
\hline 丸みのあるー角ばった & -0.547 & -0.020 & 0.366 & 0.433 \\
\hline 強い一弱い & 0.519 & 0.506 & -0.177 & 0.557 \\
\hline 鮮明なーぼんやりした & 0.022 & 0.589 & 0.057 & 0.350 \\
\hline 硬いー軟らかい & 0.423 & 0.493 & -0.424 & 0.603 \\
\hline 明るいー暗い & -0.153 & 0.217 & 0.714 & 0.580 \\
\hline 美しいー醜い & -0.261 & 0.405 & 0.571 & 0.559 \\
\hline 温かいー冷たい & 0.121 & -0.087 & 0.506 & 0.279 \\
\hline 寄与度 & 2.733 & 1.139 & 1.469 & 5.341 \\
\hline 因子寄与率 (\%) & 27.328 & 11.394 & 14.688 & 53.411 \\
\hline
\end{tabular}

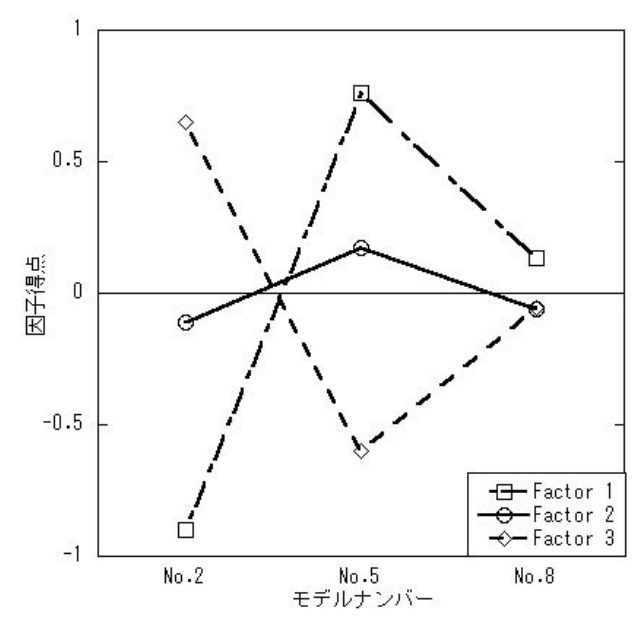

図 9 代表型断面モデルの因子得点

\section{4. 結 論}

本研究では, ペットボトルモデルを対象として, デザイン の差異による印象の差を検討した。本研究より以下の点が明 らかとなった。

（1）アンケート結果に関して，丸型断面モデル内では変形し やすさという点で, 差異を感じさせない結果を示した。 角型断面モデル内では，平均值の傾向はモデルに依らず 一致し, 分散分析の結果より, 溝の位置が上と下の場合 に印象に差がなく，同様の結果となった。六角型断面モ デル内では, 肩の位置の微妙な違いで有意な差が見られ たのは一つの形容詞対のみで, 他に関しては差が見られ なかった。代表型に関しては，その形状が丸型と角型の 中間に位置する六角型ではあるが, すべての形容詞対に 関して中間の值とならずに，丸型に近い場合と角型に近 い場合が見受けられた。

（2）本研究で用いた形容詞対によれば，丸型断面モデルに対 する印象は「強さ」,「明るさ」,「ジェンダー」の3因子, 角型断面モデルの印象は「強さ」,「明るさ」の 2 因子, 六角型断面モデルの印象は「重厚さ」,「機能美」,「明る 
さ」の3因子, 代表型に対する印象は「重厚さ」,「感触」, 「明るさ」の 3 因子から構成されていると考えられる。

（3）因子得点については, 丸型断面モデルにおいて, どの因 子の因子得点においても, 一つのモデルが他の二つと異 なる印象を与える結果を得た．角型断面モデルに関して は，因子に拘らず，グラフに拈ける形状による傾向は一 致した。「明るさの因子」に関しては，溝の位置に拘ら ず有意な差は見出せなかった，六角型断面モデルに関し ては, アンケート結果と同様の傾向が見られた。代表型 断面モデルに関しては, 「感触の因子」の因子得点は「重 厚さ」,「明るさ」因子の間に位置した。また六角型断面 モデルの因子得点は，丸型と角型の間の值をとった。

今回の評価手続きは断面モデルの単独提示であり, 複数の 断面モデルを同時に提示した際は異なる傾向になることも考 えられる，例えば六角型断面モデルのように，二つを並べ比 較しなければ認識が困難な微妙な違いでは, 単独提示では現 れなかった差が出現する可能性はある。同時に, 溝の位置の ように僅かな外観デザインの相違によって印象に差が出る場 合があった。このように，人が目で認識できるデザインに関 しては, 微妙な部分の差異でも検討の必要性があるといえる.

\section{参 考 文 献}

[1] 上崎浩子: 新たな造形テイストへの挑戦, 日本機械学会誌, 112, pp.940-941, 2009

[2] Lai, H.H., Lin, Y.C., Yeh, C.H., Wei, C.H.: User-oriented Design for the Optimal Combination on Product Design, Int. J. Production Economics, 100, pp.253-267, 2006.

[3] 李美龍, 李昇姫：触感に基づいた厚さの印象評価, 日本感 性工学会論文誌，9，pp.1-9, 2009.

４4］原田利宣：事例に基づく自動車外形形状デザイン支援シス テム，第 18 回人工知能学会全国大会，1E3-02， 2004.

[5] 原田利宣, 森典彦, 杉山和雄 : 曲線の性質に関する定量化 研究, デザイン学研究, 40, 6, pp.9-16, 1994.

６］矢澤宗厚, 市橋孝太, 大島康彰, 成田吉弘：様々な曲面を
持つ柱状体に関する感性工学的研究, 第 11 回日本感性工 学会大会講演論文集, 3G3 - 4, 2009

[7] 小林重順 : カラーシステム (改訂版), 講談社, pp.68-69, 1999.

[8］岩下豊彦：SD法によるイメージの測定：その理解と実施 の手引, 川島書店, 1983 .

[9] Mendoza, J.L.: A Significance Test for Multisample Sphericity, Psychometrika, 45, pp.495-498, 1980.

[10］堀啓造：因子数決定法, 斜交回転法, 階層因子分析 <http://www.ec.kagawa-u.ac.jp/ hori/yomimono/fnumber.ppt> （最終アクセス日 2010/07/06）

[11] Greenhouse, S.W. and Geisser, S.: On Methods in the Analysis of Profile Data, Psychometrika, 24, pp.95-112, 1959.

[12] 渡辺利夫：フレッシュマンから大学院生までのデータ解 析・R言語, ナカニシヤ出版, pp.33-47, 2005.

[13] 永田靖, 吉田道弘: 統計的多重比較法の基礎, サイエンティ スト社, pp95-102, 1997.

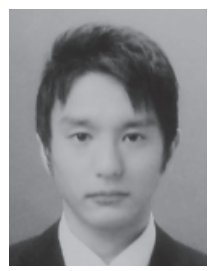

矢澤 宗厚 (学生会員)

2008 年北海道大学工学部機械工学科卒業. 2010 年 3 月, 北海道大学大学院工学研究科人 間機械システムデザイン専攻修士課程修了. 現在, パナソニック電工株式会社勤務.

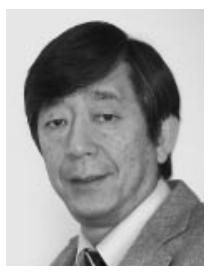

成田 吉弘 (正会員)

1980 年北海道大学大学院博士後期課程修 了, 工学博士. 1980 2004 年北海道工業大 学勤務. 現在, 北海道大学工学研究院教授, 副研究院長. この間, 機械力学, システム工 学, 複合材料工学, 設計工学, 工学教育, 感 性工学に関する研究に従事. 日本機械学会の部門長, 支部長, 論文集編修委員長, 評議員などを経て現在, 庶務理事. その他, 日本複合材料学会理事, ASME AMR 副編集長など. 